\title{
Perbandingan Kinerja Pembangunan Manusia dan Sosial Ekonomi Pasca Pemekaran Wilayah
}

\section{Comparison of Human Development and Socio-Economic Performance Post Regional Expansion}

\author{
${ }^{1}$ Ammar Hattami, ${ }^{2}$ Darol Arkum \\ 1,2Program Studi Ilmu Administrasi Negara, Stisipol Pahlawan 12 Sungailiat
}

Disetujui: Oktober 2021; Direview: Nopember 2021;Diterima: Nopember 2021

\begin{abstract}
Abstrak
Mengevaluasi Daerah Otonomi Baru, tentunya perlu strategi dalam memilih variabel, indikator dan metode yang digunakan, agar hasil yang didapat dapat bermanfaat bagi perbaikan sekaligus peningkatan. Salah satu cara untuk dijadikan dasar pembanding yang tepat dan akurat adalah dari kinerja Pembangunannya antara daerah pemekaran dengan Induknya. Tujuan dari penelitian ini adalah untuk mengetahui apakah ada perbedaan kinerja pembangunan manusia dan sosial ekonomi pasca pemekaran wilayah dan seberapa besar perbedaannya dengan lokus penelitian di Provinsi Kepulauan Bangka Belitung dan Sumatera Selatan. Metode penelitian yang digunakan adalah kuantitatif dengan jenis penelitian yang bersifat komparatif atau membandingkan. Pengumpulan data dalam penelitian ini dengan cara dokumentasi dan studi pustaka, menggunakan jenis data sekunder. Temuan penelitian menunjukkan tidak ada perbedaan kinerja pembangunan manusia dan pembangunan sosial pasca pemekaran wilayah, namun kinerja pembangunan ekonomi terdapat perbedaan setelah pemekaran wilayah pada periode 2005 2019. Besarnya selisih atau perbedaan kinerja pembangunan ekonomi adalah 0,42, termasuk dalam kategori kecil. Penelitian ini diharapkan dapat menjadi acuan bagi pihak Pemerintah Provinsi Kepulauan Bangka Belitung dalam meningkatkan kinerja pembangunan manusia dan sosial ekonomi, agar fokus pada program pemberdayaan masyarakat miskin serta mengurangi angka pengangguran dengan membuka lapangan kerja.
\end{abstract}

Kata Kunci: Perbandingan, Kinerja, Pembangunan Manusia, Sosial Ekonomi

\section{Abstract}

Evaluating the New Autonomous Region, of course, requires a strategy in choosing the variables, indicators and methods used, so that the results obtained can be useful for improvement as well as improvement. One way to make a precise and accurate basis for comparison is from the performance of its development between the new expansion area and its parent. The purpose of this study was to determine whether there were differences in the performance of human and socio-economic development after the division of the region and how big the difference was with the research locus in the Provinces of the Bangka Belitung Islands and South Sumatra. The research method used is quantitative with the type of research being comparative or comparing. Collecting data in this study using documentation and literature study, with the type of secondary data. The research findings show that there is no difference in the performance of human development and social development after regional expansion, but there is a difference in the performance of economic development after regional expansion in the period 2005-2019. The magnitude of the difference or difference in the performance of economic development is 0.42 and is included in the small category. This research is expected to be a reference for the Provincial Government of the Bangka Belitung Islands in improving the performance of human and socioeconomic development, so that it focuses on empowering the poor and reducing unemployment by creating job opportunities.

Keywords: Comparison, Performance, Human Development, Socio-Economic

How to Cite : Hattami, A. (2021). Perbandingan Kinerja Pembangunan Manusia dan Sosial Ekonomi Pasca Pemekaran Wilayah. PUBLIKAUMA: Jurnal Ilmu Administrasi Publik UMA, Vol. 9 (2): 55-63

\begin{tabular}{ll}
\hline *Corresponding author: & ISSN 2549-1660 (Print) \\
E-mail: $\underline{\text { hafizhrizquallah@gmail.com }}$ & ISSN 2580-2011 (Online)
\end{tabular}




\section{PENDAHULUAN}

Pembentukan Daerah Otonomi Baru atau DOB adalah sebutan lain dari pemekaran wilayah untuk memberikan peluang bagi daerah untuk mengelola dan memelihara sumber daya nasional yang dimilikinya berdasarkan peraturan perundangan, sesuai dengan amanat Undang-Undang No. 23 Tahun 2014 tentang Pemerintahan Daerah. Dengan diberlakukannya Undang-Undang ini kemudian dibarengi dengan era reformasi sudah memberikan ruang lebih terbuka kepada masyarakat untuk mengembangkan dan membangun diri sendiri. Sehingga menimbulkan fenomena masyarakat dalam berbagai wilayah untuk membentuk DOB, baik wilayah provinsi maupun kabupaten atau kota. Keinginan itu dipicu adanya dinamika sosial, ekonomi, politik maupun budaya disuatu daerah atau wilayah.

Dokumen (Permendagri No.43, 2015), tentang Organisasi dan tata kerja Kementerian Dalam Negeri mencatat perkembangan pembentukan Daerah Otonomi Baru (DOB) sejak tahun 1999-2014, adalah sebanyak 223 DOB terdiri dari wilayah 8 Provinsi, 181 Kabupaten dan 34 Kota.

Menurut Ida dalam (Hakim, A., Hamidi, W., \& Tampubolon, 2017), pemekaran wilayah bukanlah solusi utama bagi daerah dalam meningkatkan tingkat kesejahteraan masyarakat di daerahnya. Begitu juga menurut Fitriani et al. dalam (Hakim, A., Hamidi, W., \& Tampubolon, 2017a), pemekaran wilayah akan memberikan peluang atau kesempatan untuk memperoleh keuntungan berupa dana dari pemerintah pusat maupun penerimaan dari daerah sendiri. Namun, daerah dituntut semaksimal mungkin dalam hal mengimbangi antara kebutuhan dan kemampuannya menggali potensi daerah, dalam rangka upaya peningkatan pendapatan melalui pendapatan asli daerah (PAD).

Evaluasi dari berbagai pihak, bagaimana hasil dari pembentukan DOB diantaranya ada perkembangan yang positif dan ada yang perkembangan negatif. Beberapa pendapat para peneliti, pengamat dari kalangan pemerintah maupun swasta dalam memberikan gambaran dampak dari pembentukan DOB adalah sebagai berikut:
Sujianto dalam (Hakim, A., Hamidi, W, \& Tampubolon, 2017b), pembentukan DOB seyogianya adalah untuk memberikan kesejahteraan dan kemakmuran masyarakat, namun dibeberapa wilayah otonom banyak menimbulkan masalah baru. Dalam pidato kenegaraan Presiden Republik Indonesia pada tanggal 16 Agustus 2010 terkait evaluasi pelaksanaan pemerintahan Kabupaten/Kota yang baru hanya $20 \%$ yang berhasil, selebihnya $80 \%$ dinyatakan gagal dalam pelaksanaan pemerintahan dan pembangunan didaerah otonom yang baru. Begitu juga dengan hasil study terkait evaluasi dampak pemekaran daerah oleh Badan Perencanaan Pembangunan Nasional kerjasma dengan United Nations Development Programme (UNDP) dalam (Pradana, 2020), menyimpulkan bahwa Daerah Otonomi Baru berada dalam kondisi yang tidak lebih baik apabila dibandingkan dengan daerah induknya.

(Kurniawati, 2012), menyatakan pemekaran wilayah telah mendorong Provinsi Kepulauan Bangka Belitung dalam peningkatan pemerataan pelayanan kesehatan, khususnya bidang pengadaan sarana fisik. Secara umum dikatakannya bahwa IPM, tingkat kemiskinan dan pengangguran daerah otonomi baru lebih rendah daripada di daerah induk, hal ini disebabkan daerah otonomi lebih memprioritaskan pada peningkatan aktifitas ekonomi. Pernyataan ini didukung oleh data rata-rata laju pertumbuhan Produk Domestik Regional Bruto (PDRB) dilima dari tujuh DOB yang berada diatas rata-rata nasional, yaitu Provinsi Kepulauan Bangka Belitung, Provinsi Kepulauan Riau, Gorontalo, Sulawesi Barat, dan Papua Barat (BAPPEDA Kabupaten Belitung, 2021).

Selanjutnya menurut Lincolin dalam (Pradana, 2020a), pada dasarnya tujuan dari Otonomi daerah atau pemekaran wilayah adalah untuk meningkatkan pertumbuhan ekonomi yang sekaligus berdampak pada kesejahteraan masyarakat. Artinya dengan adanya pemekaran wilayah, diharapkan daerah akan lebih leluasa dalam mengelola segenap potensi ekonomi yang ada secara optimal didaerah tersebut dalam rangka mengurangi angka kemiskinan. 
Todaro dan Smith dalam (Pradana 2020b), menyatakan optimalisasi potensi sumber daya daerah dari aspek ekonomi, sosial dan pemerintahan akan bisa tercapai dengan adanya kebijakan desentralisasi.

Dengan adanya hasil evaluasi, hasil penelitian maupun pendapat dari para ahli diatas menunjukkan adanya perbedaan pendapat terkait pemekaran wilayah. Sehingga menurut penulis sangatlah relevan penelitian yang berjudul "Perbandingan Kinerja Pembangunan Manusia dan Sosial Ekonomi Pasca Pemekaran wilayah" (studi di Provinsi Kepulauan Bangka Belitung dan Sumatera Selatan tahun 2005-2019), ini dilakukan untuk memperoleh informasi apakah dalam pelaksanaannya pengelolaan sumber daya yang ada didaerah ini sudah sesuai dengan harapan.

Tujuan dari penelitian ini adalah untuk mengetahui apakah ada perbedaan Kinerja Pembangunan Manusia dan Pembangunan Sosial Ekonomi Pasca Pemekaran Wilayah di Provinsi Kepualauan Bangka Belitung dengan Provinsi Sumatera Selatan. Disamping itu untuk mengetahui seberapa besar perbedaan Kinerja Pembangunan Manusia dan Pembangunan Sosial Ekonomi tersebut.

\section{METODE PENELITIAN}

Lokasi penelitian di Provinsi Kepulauan Bangka Belitung dan Provinsi Sumatera Selatan, penelitian dilaksanakan selama 6 bulan yaitu bulan April-September 2021 dengan kegiatan sebagai berikut:

Tabel 1. Jadwal penelitian

\begin{tabular}{|c|l|l|l|l|l|l|}
\hline \multirow{2}{*}{ Kegiatan } & \multicolumn{5}{|c|}{ B u l a n } \\
\hline & & & & & & \\
\hline $\begin{array}{c}\text { Perijinan } \\
\text { Penelitian, } \\
\text { Observasi Lokasi }\end{array}$ & & & & & & \\
\hline $\begin{array}{c}\text { Penyusunan } \\
\text { Proposal Penelitian }\end{array}$ & & & & & & \\
\hline $\begin{array}{c}\text { Pelaksanaan } \\
\text { Penelitian }\end{array}$ & & & & & & \\
\hline $\begin{array}{c}\text { Penyampaian } \\
\text { Laporan hasil } \\
\text { penelitian }\end{array}$ & & & & & & \\
\hline
\end{tabular}

\begin{tabular}{|l|l|l|l|l|l|l|}
\hline $\begin{array}{c}\text { Seminar Hasil } \\
\text { Penelitian }\end{array}$ & & & & & & \\
\hline $\begin{array}{c}\text { Revisi Hasil } \\
\text { Penelitian }\end{array}$ & & & & & & \\
\hline
\end{tabular}

Sumber : Diolah peneliti

Metode penelitian yang digunakan adalah Kuantitatif dengan jenis penelitian bersifat komparatif, menurut (Sudaryono, 2019), penelitian komparatif adalah penelitian yang bersifat membandingkan suatu fenomena, peristiwa, gejala pada satu populasi atau sampel yang satu dengan sampel yang lain, atau waktu tertentu dengan waktu yang lain dengan menggunakan data kuantitatif maupun kualitatif.

Metode Pengumpulan data dalam penelitian ini dengan cara sebagai berikut: 1) Studi Pustaka; dengan mengumpulkan data yang relevan dari buku, artikel ilmiah, berita, maupun sumber kredibel lainnya yang terkait dengan topik penelitian. 2) Dokumentasi; pengumpulan data berupa data IPM, tingkat kemiskinan, tingkat pengangguran dan pertumbuhan ekonomi yang bersumber dari Badan Pusat Statistik, BPS Provinsi Kepulauan Bangka Belitung dan BPS Provinsi Sumatera Selatan.

Populasi yang digunakan dalam penelitian ini adalah data Indeks Pembangunan Manusia, tingkat kemiskinan, tingkat pengangguran dan pertumbuhan ekonomi berupa publikasi tahunan yang diterbitkan oleh Badan Pusat Statistik selama 20 tahun terakhir yaitu tahun 2000 sampai dengan tahun 2020. Populasi ditentukan dengan cara melihat mulai terbentuknya Provinsi Kepulauan Bangka Belitung atau dimulai pada saat terjadi pemekaran wilayah dari Provinsi Sumatera Selatan pada tahun 2000 hingga sekarang pada tahun 2020. Dengan demikian populasi bisa dinyatakan ada sebanyak 20 dengan satuan tahun.

Sampel yang dijadikan objek penelitian hanya selama 15 tahun terakhir yaitu dari tahun 2005 sampai dengan tahun 2019, menggunakan metode purporsive sampling (penarikan sampel dengan pertimbangan). Pertimbangan dalam pengambilan sampel penelitian ini adalah untuk memenuhi asumsi atau persyaratan statistik parametrik dengan menggunakan uji-t (uji beda) yang memerlukan distribusi data yang normal. 
Selanjutnya Untuk membuktikan bahwa data IPM, tingkat kemiskinan, tingkat pengangguran dan pertumbuhan ekonomi selama 15 tahun terakhir berdistribusi normal, maka dilakukan pengujian normalitas data dengan menggunakan Uji KolmogorovSmirnov Goodness of Fit.

Uji hipotesis yang digunakan dalam penelitian ini adalah Uji beda rata-rata dua sampel tidak berhubungan (Uji t), menurut (Sarwono, 2018), uji $\mathrm{t}$ sampel tidak berhubungan adalah uji yang digunakan untuk membandingkan rata-rata dua kelompok kasus. Dengan catatan kedua sampel mempunyai varians yang sama, berdistribusi normal dengan skala data interval.

Menurut Rosenthal dalam (H. Latan, 2014), untuk mengetahui besaran nilai perbedaan beserta kriteria nilainya, maka digunakan formula effectsize (r), sebagai berikut:

$$
\text { Effectsize }(r)=\sqrt{ } \frac{t^{2}}{\sqrt{t^{2}+d f}}
$$

Catatan: $\mathrm{t}=\mathrm{t}$-statistik

$$
\mathrm{df}=\text { degree of freedom }
$$

Dengan kriteria nilai effect size adalah sebagai berikut: 1) Effectsize $=0,25 \geq r>0,50$ : kecil, 2) Effectsize $=0,50 \geq r>0,75$ : menengah, 3) Effectsize $=r \geq 0,75$ : besar.

\section{HASIL DAN PEMBAHASAN Analisis Perbandingan pembangunan Manusia}

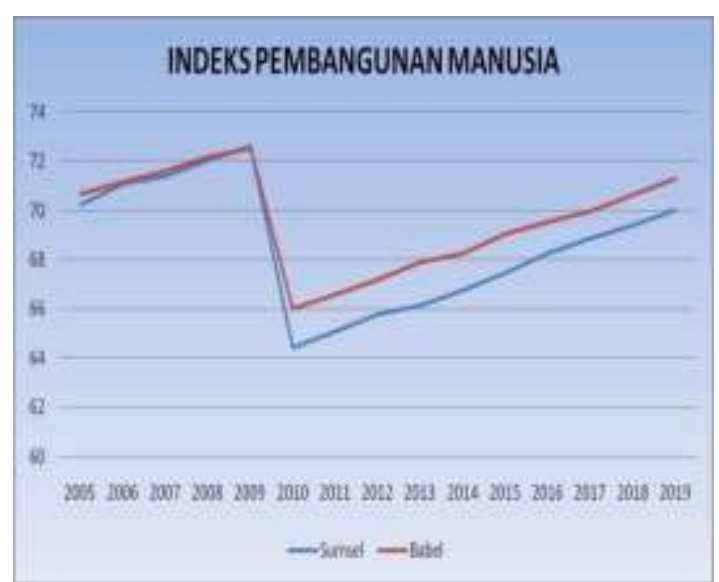

Sumber: BPS, 2005-2019

Gambar 1. Perkembangan IPM
Gambar 1. selama 15 tahun terakhir menunjukkan bahwa IPM di kedua Provinsi baik provinsi induk maupun pemekaran dengan trend atau kecenderungan arah yang sama, yaitu trend yang menaik. Namun pada tahun 2010 terjadi penurunan yang signifikan, salah satu penyebabnya adalah adanya perubahan metode penghitungan angka IPM yaitu dari metode rata-rata aritmatik menjadi rata-rata geometric. Menurut (Badan Pusat Statistik, 2015), Penggunaan metode baru dalam penghitungan IPM menimbulkan sejumlah konsekuensi. Dampak langsung penggunaan metode baru adalah angka IPM akan menjadi lebih rendah dibanding dengan penggunaan metode lama, disebabkan adanya penambahan indikator Harapan Lama Sekolah pada penghitungan Indeks Pendidikan.

Periode selanjutnya (2010-2019) telah terjadi peningkatan angka yang cukup berarti yaitu dari angka 66,02 tahun 2010 menjadi 71,30 pada tahun 2019 artinya telah terjadi peningkatan angka sebesar 5,28 point. Menunjukkan usaha yang dilakukan oleh pemerintah provinsi kepulauan Bangka Belitung dalam membangun manusianya sudah menampakkan kemajuan, dengan merubah kategori cukup baik menjadi kategori baik dari sisi pembangunan manusia.

Jika dibandingkan dengan provinsi induknya yaitu Sumatera selatan, selama 15 tahun terakhir (2005-2019) tidak ada perbedaan yang nyata. Secara absolute ratarata IPM di Provinsi Kepulauan Bangka Belitung adalah 69,65, sedangkan Provinsi Sumatera Selatan 68,64 , hanya berbeda 1,01 point. Dari hasil uji beda rata-rata yang dilakukan, peneliti menyimpulkan bahwa kinerja provinsi pemekaran tidak kalah dengan provinsi induknya dalam hal usaha atau upaya membangun sumber daya manusia dibidang pendidikan, kesehatan dan pengeluaran perkapita atau daya beli masyarakatnya.

Menurut (BAPPEDA Provinsi Kepulauan Bangka Belitung, 2020), peningkatan angka IPM provinsi ini, karena adanya peningkatan angka IPM Kabupaten/Kota. IPM tertinggi ada di Kota Pangkal Pinang, terendah ada di Kabupaten Bangka Selatan. Kenaikan angka IPM Provinsi dipicu oleh kenaikan dari masing-masing indikator; Indikator Angka 
Harapan Hidup, Rata-Rata Lama Sekolah, Harapan Lama Sekolah dan Pengeluaran perkapita yang disesuaikan. (https://bappeda.babelprov.go.id/content/pe ngaruh-indeks-pembangunan-manusia-ipmdan-pertumbuhan-ekonomi-terhadapkemiskinan, diunduh tgl. 13 juli 2021).

Kepala BPS Provinsi Sumatera Selatan, (Wahyuningsih, E. T., 2019), mengatakan bahwa pencapaian pembangunan manusia diukur dengan memperhatikan tiga aspek esensial, yaitu umur panjang dan hidup sehat, pengetahuan, dan standar hidup layak. Pembangunan manusia Sumatera Selatan terus mengalami peningkatan selama periode 20102019 dilihat dari indicator yang menjadi komponen

IPM.

(https://www.antaranews.com/berita/83 $1287 /$ bps-indeks-pembangunan-manusia-disumsel-meningkat, diunduh tgl.13 Juli 2021)

\section{Analisis Perbandingan Pembangunan Sosial}

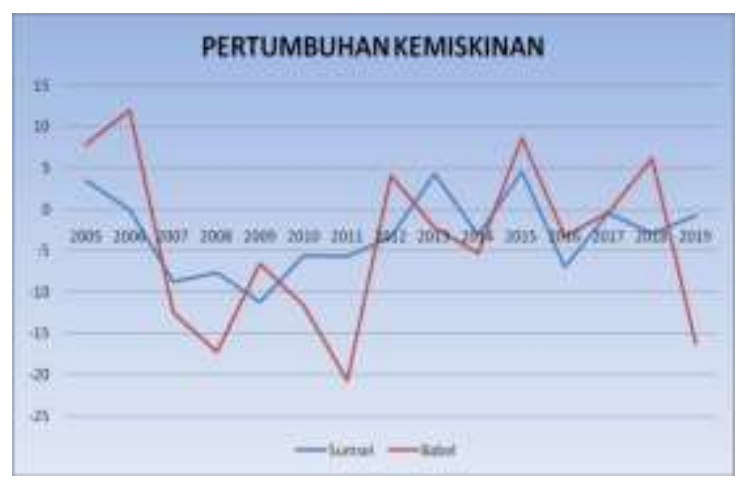

Sumber: BPS, 2005-2019 (diolah)

Gambar 2 pertumbuhan kemiskinan

Gambar 2. menujukkan bahwa pertumbuhan tingkat kemiskinan selama 15 tahun terakhir di kedua provinsi dengan trend yang sangat fluktuatif. Secara kasat mata agak sulit membayangkan angka rata-rata pertumbuhannya. Hasil uji beda rata-rata (uji t) pertumbuhan kemiskinan di Provinsi Kepulauan Bangka Belitung adalah sebesar 3,82 persen, rata-rata pertumbuhan tingkat kemiskinan di Provinsi Sumatera Selatan - 2,95 $\%$. Nilai signifikasinya lebih besar dari nilai alpha 5 persen sehingga kesimpulannya bahwa rata-rata pertumbuhan tingkat kemiskinan di provinsi Kepulauan Bangka Belitung dan provinsi Sumatera Selatan adalah relatif sama atau dengan kata lain tidak ada perbedaan yang signifikan terkait penurunan angka kemiskinan.

Secara absolut tingkat kemiskinan samasama mengalami penurunan yang cukup berarti, dilihat dari angka kemiskinan 9,74 persen menjadi 4,62 persen pada tahun 2019 . Provinsi Sumatera Selatan dari 21,01 persen turun menjadi 12,71 persen. Artinya sejak terjadi nya pemekaran wilayah, provinsi Kepulauan Bangka Belitung telah melakukan berbagai upaya agar penduduk yang masuk kategori miskin berkurang.

"Menurut (Yulianti. A, 2020), kemiskinan yang terjadi di Kabupaten/Kota Provinsi Kepulauan Bangka Belitung erat kaitannya dengan pendidikan dan kesehatan masyarakat yang belum optimal. Pemerintah berperan penting dalam mengoptimalkan peningkatan sumber daya manusia atau modal manusia (Human Capital) dengan menstimulus riset dan pemajuan dalam meningkatkan produktivitas manusia yang merupakan teori pertumbuhan ekonomi baru. Pendidikan memiliki peranan penting dalam meningkatkan kemampuan untuk menyerap teknologi modern dan mengembangkan kapasitas dalam mewujudkan pertumbuhan serta pembangunan.

Selain itu, untuk kesehatan menjadi syarat dalam meningkatkan produktivitas, karena dengan kesehatan, pendidikan mudah dicapai. Dalam hal ini, kesehatan dan pendidikan merupakan komponen penting pembangunan ekonomi dalam membantu mengurangi kemiskinan. Dengan pendidikan dan kesehatan maka pendapatan tinggi akan mudah diperoleh. Begitu sebaliknya dengan pendapatan tinggi maka akan mudah mengeluarkan dana untuk kesehatan dan pendidikan. Pada sector informal seperti pertanian, ketika ada peningkatan keterampilan dan keahlian tenaga kerja, maka akan dapat meningkatkan hasil pertanian. Karena dengan adanya tenaga kerja terampil yang bekerja lebih baik, maka produktivitas meningkat dan pada akhirnya kesejahteraan akan lebih baik. Hal ini dapat dilihat dari bertambahnya pendapatan peningkatan konsumsi".

(http://bappeda.babelprov.go.id/content/pen garuh-indeks-pembangunan-manusia-ipm- 
dan-pertumbuhan-ekonomi-terhadapkemiskinan, diunduh tanggal 30 Juni 2021)

"Menurut (Bappeda Provinsi Sumatera Selatan, 2014), penurunan kemiskinan di Sumatera Selatan tidak lepas dari dukungan beberapa indikator utama maupun indikator pendukung kemiskinan. Dari beberapa indikator utama dapat disimpulkan bahwa masih ada beberapa indikator yang angkanya masih rendah dan perlu perhatian lebih lanjut, diantaranya angka morbiditas (kesakitan), Angka kematian Bayi, AngkaPartisipasi Kasar SMA, Proporsi RT dengan Akses Air bersih, Proporsi Rt dengan akses sanitasi layak serta masih tingginya harga beras dan kebutuhankebutuhan pokok disetiap tahunnya. Apabila Indikator tersebut dan beberapa indicator lainnya ditingkatkan maupun dilakukan tindak lanjut dan akselerasi yang komprehensif, bukan tidak mungkin angka kemiskinan di Provinsi Sumatera Selatan dapat jauh lebih cepat mengalami penurunan dimana akan berimbas meningkatnya perekonomian di Provinsi Sumatera Selatan". (http://bappeda.sumselprov.go.id/userfiles/fil es/1427691072 1200816491.pdf, diunduh tanggal 30 Juni 2021)

Menurut Bank Dunia dalam (Haughton, 2012), penyebab timbulnya kemiskinan adalah kurangnya kesejahteraan, dalam arti masyarakat tidak memiliki atau kurang memadai dalam kemampuan utama, seperti; pendapatan, pendidikan, kesehatan, rasa aman, kepercayaan diri, dan kebebasan berbicara, memenuhi kebutuhan pokok atau kebutuhan hidup layak. Kebutuhan hidup layak diukur dengan garis kemiskinan, yang didefinisikan jika pendapatan atau pengeluaran seseorang berada dibawah garis kemiskinan tersebut maka dia dinyatakan miskin (Maipita, 2013).

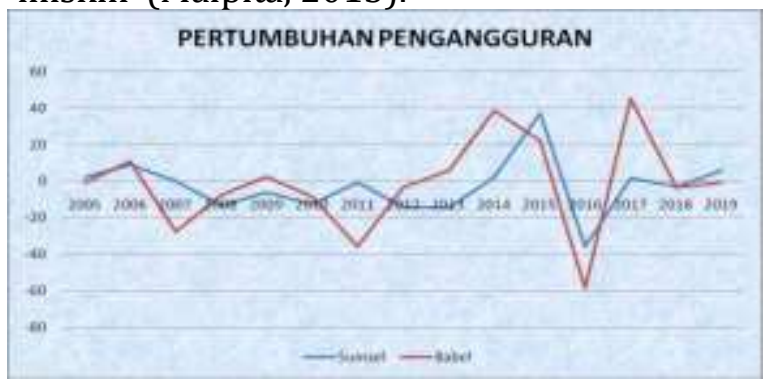

Sumber : BPS, 2005-2019 (diolah)

Gambar 3. Pertumbuhan tingkat pengangguran
Informasi yang kita dapatkan dari Gambar. 3. adalah bahwa pertumbuhan tingkat pengangguran selama 15 tahun terakhir dikedua provinsi menunjukkan trend yang cukup fluktuatif. Hasil uji beda rata-rata pertumbuhan tingkat pengangguran di Provinsi Kepulauan Bangka Belitung adalah sebesar $-1,40$ persen, sedangkan Sumatera Selatan adalah - 2,71\%. Signifikansinya $(0,871)$ $>$ alpha $(0,05)$, kesimpulannya adalah rata-rata pertumbuhan tingkat pengangguran di provinsi Kepulauan Bangka Belitung dan provinsi Sumatera Selatan relative sama.

Menurut Marhaeni dan Manuati dalam (Fitriana, 2019), faktor-faktor yang mempengaruhi tingkat pengangguran adalah: tingkat upah, teknologi, fasilitas modal, struktur perekonomian, pertumbuhan ekonomi yang rendah. Faktor lain adalah oleh ketidakmampuan pasar kerja dalam menyerap angkatan kerja yang ada. Lapangan kerja yang terbatas tidak mampu menampung para pencari kerja yang semakin meningkat seiring dengan meningkatnya jumlah penduduk (Badan Pusat Statistik, 2013)

(Rosman. E, 2020), menyatakan tingkat pengangguran di Kepulauan Bangka Belitung 3,62 persen tahun 2019, dibawah tingkat pengangguran Nasional yakni 5,82 persen. Dampak dari penurunan tingkat pengangguran adalah menurunkan tingkat kemiskinan, meningkatkan daya beli masyarakat, menurunkan tingkat inflasi serta ketimpangan ekonomi. Ketimpangan ekonomi dilihat dari angka Gini Ratio Provinsi Kepulauan Bangka Belitung sebesar 0,262 persen, dan merupakan angka ketimpangan pengeluaran penduduk yang terendah di Indonesia.

(https://regional.kompas.com/read/2020/12 /14/2229316/sepak-terjang-gubernurerzaldi-rosman-bangun-bangka-belitung, diunduh tgl. 30 Juni 2021. 


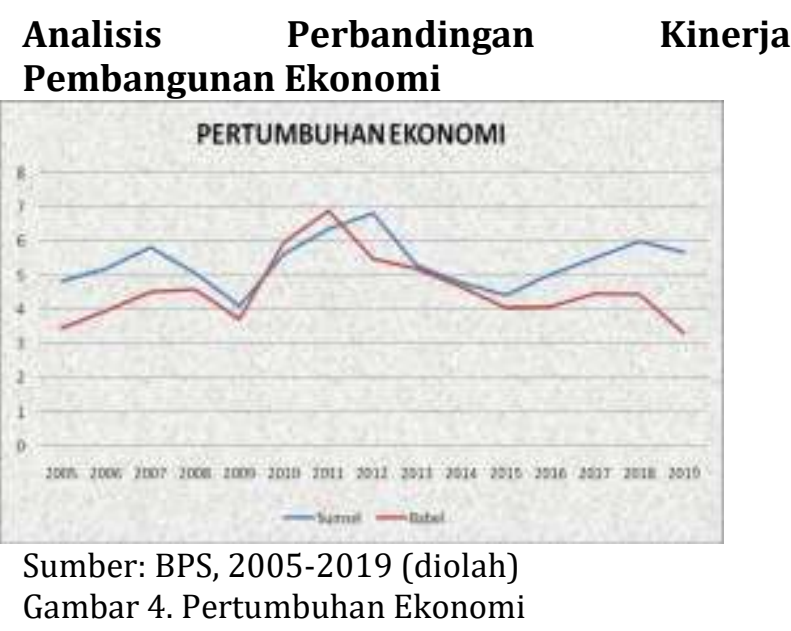

Secara umum pertumbuhan ekonomi dihitung berdasarkan data Produk Domestik Regional Bruto atas dasar harga konstan (PDRB ADHK). Gambar 4. memberikan informasi bahwa pertumbuhan ekonomi selama 15 tahun terakhir dikedua provinsi dengan trend yang sama-sama positif. Hasil uji beda rata-rata dapat diakatakan bahwa ratarata pertumbuhan ekonomi di Provinsi Kepulauan Bangka Belitung adalah sebesar 4,60 persen, Sumatera Selatan sebesar 5,38 persen. Hasil Uji beda rata-rata (uji t) nilai Signifikansi sebesar $(0,019)<$ nilai alpha $(0,05)$, sehingga dapat dikatakan bahwa ratarata pertumbuhan ekonomi di provinsi Kepulauan Bangka Belitung dengan provinsi Sumatera Selatan berbeda.

Provinsi Kepulauan Bangka Belitung rata-rata pertumbuhan ekonominya lebih rendah dari provinsi induknya. Namun perbedaan tersebut hanya sebesar 0,42 dilihat dari kriteria nilai effect size (r) Rosenthal dalam (Latan, 2014), perbedaan rata-rata pertumbuhan ekonomi antara provinsi pemekaran dengan provinsi induk nya masuk kategori kecil atau rendah.

Menurut (Pemerintah Provinsi Kepulauan Bangka Belitung, 2015), dalam Laporan Kinerja Provinsi Kepulauan Bangka Belitung menyatakan: "Laju Pertumbuhan ekonomi Kepulauan Bangka Belitung tumbuh sebesar 4,08 persen mengalami perlambatan jika dibandingkan dengan pertumbuhan ekonomi tahun 2014 yang sebesar 4,67 persen. Kondisi ini terjadi disebabkan beberapa faktor yaitu adanya bencana kabut asap, kemarau panjang, kenaikan harga bahan bakar minyak dan tarif dasar listrik serta terjadinya perlambatan ekonomi global dan turunnya harga minyak mentah dunia yang membawa dampak bagi perekonomian wilayah Kepulauan Bangka Belitung, namun pertumbuhan PDRB tahun 2016 akan didorong oleh stimulus fiscal terutama pembangunan proyek infrastruktur (investasi) dan konsumsi yang diperkirakan masih tetap kuat. Setelah mengalami pertumbuhan yang tinggi sebesar 6,9 persen pada tahun 2011, pertumbuhan ekonomi Bangka Belitung mengalami perlambatan menjadi 5,5 persen pada tahun 2012, melambat lagi pada tahun 2013 menjadi 5,22 persen, tahun 2014 menjadi 4,68 persen dan tahun 2015 menjadi 4,08 persen. Pelambatan pertumbuhan ekonomi ini disebabkan dari produksi sector pertambangan yang terus mengalami penurunan. Penurunan produksi ini tentunya berimbas pada sektor lainnya yang ada di Provinsi Kepulauan Bangka Belitung". (https://babelprov.go.id/dokumen/bankdata, diunduh tanggal 30 Juni 2021)

Hasil kaji banding dengan penelitian terdahulu terdapat persamaan hasil penelitian diantaranya dengan penelitian (Pradana, 2020c) dengan judul "Perbandingan Kinerja Pembangunan Sosial dan Ekonomi Kabupaten Aceh Barat dengan Kabupaten Pemekarannya tahun 2011-2019". Menggunakan metode Kuantitatif dengan pendekatan komparatif (uji beda dua rata-rata yang tidak berpasangan) yang tujuannya untuk mengetahui perbandingan kondisi kinerja pembangunan sosial dan ekonomi kabupaten pemekaran terhadap kabupaten induknya pasca pemekaran daerah. Hasil penelitian menunjukkan perbedaan kinerja pembangunan ekonomi Kabupaten Aceh Barat dengan kabupaten pemekarannya tidak signifikan.

Selanjutnya dengan penelitian (Yuliana. A, 2013), dengan judul "Analisis Kinerja ekonomi dan kesejahteraan masyarakat Kabupaten Muaraenim (kota induk) dengan kota Prabumulih (Kotabaru)". Menggunakan metode penelitian Kuantitatif deskriptif, menyatakan bahwa Kota Prabumulih pembangunan ekonomi sudah mengalami perubahan, namun belum sebaik Kabupaten Induknya. Sebaliknya 
Pembangunan manusianya sudah lebih baik dari Kabupaten induknya.

Ditinjau dari sisi perbedaan hasil penelitian ini dengan penelitian terdahulu adalah pada cakupan wilayah penelitiannya, penelitian yang dilakukan peneliti terdahulu pada level kabupaten sedangkan penelitian ini menggunakan wilayah level provinsi. Kendala yang dihadapi dalam melakukan perbandingan hasil penelitian dengan peneliti sebelumnya dengan topik yang sama adalah disebabkan masih langkanya penelitian atau riset yang terkait perbandingan kinerja pembangunan manusia dan pembangunan sosial ekonomi pasca pemekaran wilayah di level Provinsi.

\section{SIMPULAN}

Peneliti berkesimpulan bahwa selama periode penelitian yaitu dari tahun 2005 hingga tahun 2019, Provinsi Kepulauan Bangka Belitung telah banyak melakukan usaha di berbagai sektor pembangunan. Alhasil untuk menyatakan bahwa Provinsi ini telah berhasil dalam membangun sumber daya manusia, mengurangi angka kemiskinan, mengurangi angka pengangguran, dan meningkatkan Pertumbuhan ekonomi yaitu dengan cara membandingkan kinerjanya dengan kinerja provinsi induknya.

Series data 15 tahun terakhir membuktikan bahwa dilihat dari kinerja pembangunan manusia dan pembangunan sosial seperti mengurangi angka kemiskinan dan angka pengangguran ternyata sama dengan provinsi induknya dalam arti tidak ada perbedaan. Perbedaan terjadi hanya pada pembangunan ekonomi dilihat dari angka pertumbuhan ekonomi yang sedikit lebih rendah dari angka pertumbuhan ekonomi provinsi Sumatera Selatan. Perbedaan tersebut tidaklah signifikan, yakni hanya sebesar 0,42 dilihat dari angka effectsize dan masuk kategori perbedaan dengan tingkat yang rendah.

Dengan demikian Provinsi Kepulauan Bangka Belitung merupakan salah satu Daerah Otonomi Baru yang terbentuk pada tahun 2000 hingga kini sudah berusia 21 tahun, bisa dikatakan berhasil membangun sumber daya manusia, juga di bidang pembangunan sosial dan ekonomi masyarakatnya. Disamping keberhasilan dalam membangun semua itu, namun masih ada kelemahan-kelemahan yang harus dibenahi yaitu dilihat dari angka pertumbuhan penurunan angka kemiskinan dan angka pengangguran menunjukkan fluktuasi yang sangat tidak stabil maupun pertumbuhan ekonomi yang masih rendah.

\section{DAFTAR PUSTAKA}

Badan Pusat Statistik. (2013). Profil Kepulauan Bangka Belitung. InJournal of Chemical Information and Modeling, Vol.53(Issue 9).

Badan Pusat Statistik. (2015). Indeks Pembangunan Manusia 2014 Metode baru, Jakarta: BPS

Bappeda Kabupaten Belitung. (2021). kemandirian fiskal provinsi kepulauan bangka belitung dan kabupaten belitung pasca desentralisas. Bappeda Belitung. bappeda.belitungkab.go.id/kemandirianfiskal-provinsi-kepulauan-bangka-belitungdan-kabupaten-belitung-pasca desentralisasi/diunduh tanggal 23 April 2021)

Bappeda Provinsi Kepulauan Bangka Belitung. (2020). Pengaruh Indeks Pembangunan Manusia (IPM) dan Pertumbuhan Ekonomi terhadap Kemiskinan Kabupaten/Kota di Provinsi Babel periode 2010-2019. http://bappeda.babelprov.go.id/content/pe ngaruh-indeks-Pembangunan-manusia ipm

Bappeda Provinsi Sumatera Selatan. 2014. Profil kemiskinan daerah Sumsel. http://bappeda.sumselprov.go.id/userfiles/f iles/1427691072_1200816491.pdf, diunduh tanggal 30 Juni 2021

Fitriana, S. (2019). Pengaruh pertumbuhan ekonomi terhadap pengangguran dan kemiskinan di Provinsi Jambi. UIN SUTHA JAMBI.

Hakim, A., Hamidi, W., \& Tampubolon, D. (2017). Analisis Dampak Pemekaran daerah ditinjau dari aspek percepatan pertumbuhan ekonomi dan peningkatan kualitas pelayanan public (Studi Pemekaran Kabupaten Kepulauan Meranti dari Kabupaten Bengkalis). Jurnal Online Mahasiswa Fakultas Ekonomi Universitas Riau.

Haughton, J. \& S. (2012). Pedoman tentang kemiskinan dan ketimpangan (Hand book on Poverty \& Inequality). Salemba Empat.

Kurniawati. (2012). Kemandirian fiscal Provinsi Kepulauan Bangka Belitung dan Kabupaten Belitung Pasca Desentralisasi. Bappeda Belitung. http://bappeda.belitungkab.go.id/kemandiri 
an-fiskal-provinsi-kepulauan-bangkatanggal 23 April 2021,

Latan, H. (2014). Aplikasi Analisis Data Statistik Untuk Ilmu Sosial Sains dengan IMB SPSS. Bandung: Alfabeta. Alfabeta.

Maipita, I. (2013). Kemiskinan, definisi dan faktor. https://www.kompas.com/Skola/read/202 0/11/24/172143169/

Pemerintah Provinsi Kepulauan Bangka Belitung. (2015). Laporan Kinerja Provinsi Kepulauan Bangka Belitung https://babelprov.go.id/dokumen/bankdata , diunduh tanggal 30 Juni 2021

Permendagri No.43 (2015) tentang Orgtanisasi dan tata kerja kementerian Dalam Negeri

Pradana, Reza Septian. (2020). Perbandingan Kinerja Pembangunan Sosial dan Ekonomi Kabupaten Aceh Barat dengan Kabupaten Pemekarannya tahun 2011-2019. Researchgate.net/publication/350785586, Juni 2020, DOI:10.22373/jep.v11i1.59.

Rosman, E. (2020). Sepak terjang gubernur Erzaldi Rosman bangun babel. Kompas.com. https://regional.kompas.com/read/2020/1 2/14/2229316/

Sarwono, J. (2018). Statistik untuk riset skripsi: CV. Andi Offset.

Sudaryono. (2019). Metodologi Penelitian Kuantitatif, Kualitatif, dan Mix Method. Rajawali Pers.

Undang-Undang No.23 Tahun 2014 tentang Pemerintahan Daerah.

Wahyuningsih, E. T. (2019). Indeks Pembangunan Manusia di Sumsel meningkat. https://www.antaranews.com/berita/8312 87/bps-indeks-pembangunan-manusia-disumsel-meningkat, diunduh tgl. 13 Juli2021

Yuliana, Anna. (2013). Analisis Kinerja Ekonomi dan Kesejahteraan Masyarakat Kabupaten Muara Enim (Kota Induk) dengan Kota Prabumulih (Kota Baru).

Yulianti, A. (2020). Pengaruh IPM dan pertumbuhan ekonomi terhadap kemiskinan.

(http://bappeda.babelprov.go.id/content/pe ngaruh-indeks-pembangunan-manusia-ipmdan-pertumbuhan-ekonomi-terhadapkemiskinan, diunduh tgl. 13 juli 2021) 